\title{
持続可能な開発目標に関する 国際会議
}

日本学術会議では、「持続可能な社会のための科学と技術に関する国際会議」を、2003年以来、 毎年継続して開催している。持続可能社会のための科学と技術という枠の中で、毎年適切なテ一 マの選択を行って実施しているものであり、2016年度は二つの会議を開催した。その一つとし て、2015年に国連において採択された持続可能な開発目標（SDGS）を主テーマとした国際会議を 2017年1月に開催した。

17のゴールと1690ターゲットを持つSDGsに関しては、世界各国で取り組みが進められてお り、日本政府としても取り組みに力を入れている。内閣総理大臣を本部長とするSDGs 推進本部が 2016年に設置され、同年12月には政府としての「SDGs 実施指針」が策定された。SDGsの前に取 り組まれていたMDGs（三レニアム開発目標）が主として開発途上国を対象にしていたのに対し、 SDGsでは日本のような先進国における課題も対象となっている。また、「誰一人取り残さない（No one left behind)」という基本方針が示されている。実際、貧困から始まるゴ一ルの多くは、日本の 社会にとっても重要な課題である。とりわけ「誰一人取り残さない」という立場で考えると、多 くの未解決の問題をわれわれは抱えている。

このように問題が多岐にわたっていることは、さまざまな人や団体を巻き込んだ議論を行いつ つ、漸進的に進めなければ、目標実現が容易でないことを意味している。この点は、Future Earthプ ログラムでも推進されている、超学際研究とマルチステークホルダ一協働の重要性と相通じるも のである。

今回の会議は、そのような背景のもとに企画されたものであった。国の内外からさまざまな方 をお招きして議論を行ったが、一般市民の方も含め多様な方の参加を得るため、同時通訳付きで 行われた。ここでは、この会議で行われた議論の一端を紹介する。もちろん、SDGsは、一度の会 議で明確な方向性が打ち出される性格の課題ではない。議論した結果もさることながら、議論を 進めるプロセスが重要である。今後もさまざまな対話、専門家の会合などを組み合わせて行くこ とが必要であろう。

日本学術会議副会長 花木啓祐 